Article

\title{
The Value of Environmental and Health Claims on New Legume Products: A Non-Hypothetical Online Auction
}

\author{
Dominic Lemken ${ }^{1, *}$, Mandy Knigge ${ }^{1}$, Stephan Meyerding ${ }^{2}$ and Achim Spiller ${ }^{2}$ \\ 1 Centre of Biodiversity and Sustainable Land Use, University of Goettingen, Platz der Göttinger Sieben 5, \\ 37073 Göttingen, Germany; mandy.knigge@agr.uni-goettingen.de \\ 2 Department of Agricultural Economics and Rural Development, University of Goettingen, \\ Platz der Göttinger Sieben 5, 37073 Göttingen, Germany; Stephan.meyerding@uni-goettingen.de (S.M.); \\ a.spiller@agr.uni-goettingen.de (A.S.) \\ * Correspondence: dlemken@gwdg.de; Tel.: +49-176-6156-2139
}

Received: 17 July 2017; Accepted: 27 July 2017; Published: 31 July 2017

\begin{abstract}
Legumes are valued in agricultural systems, as they can contribute to a more sustainable land use. However, their economic value is low. Despite health and environmental benefits, marketers struggle to communicate the worth of legumes to consumers. We evaluate the worth of health and, in particular, environmental claims that would spread consumers' awareness of ecological advantages. Utilizing a large consumer sample, we execute binding online auctions. Comparing claim-treated and untreated subjects (between design), we model the price premium that potential customers are willing to pay (WTP) for having pasta in a legume instead of a wheat version. We find that claims may increase the WTP, however, a mix of environmental and health claims is superior to individual claims. Effect sizes suggest that the mix of claims increases the WTP by roughly $35 \%$ (20 cents). The link of WTP and food attitudes, such as concern for health in eating habits or social reservations towards legumes, varies depending on whether the green-pea or chickpea pasta was evaluated. A critical perception of legumes' association with flatulence reduces the WTP. Developing the online auction may enable researchers to increase the external validity of consumer samples. We discuss implications for researchers and marketers.
\end{abstract}

Keywords: pulses; experimental auction; sustainability labels; credence attributes

\section{Introduction}

Legumes summarise a family of plants, e.g., peas, beans, lupines, and more, that have all struggled to be marketed for human consumption. Nutritional recommendations range up to 20-35 g/capita/day [1], while the consumption averages were between 2 and $4 \mathrm{~g} /$ capita/day in Germany, and 7-8 g/capita/day in Europe [2]. Medical literature supports the recommendations, as legumes protect against coronary heart disease, type II diabetes, and high blood pressure [3,4]. Some researchers have highlighted the lack of publicity and the lack of modern marketing campaigns surrounding these commodities [5,6]. Such marketing efforts could address health and ecological advantages, which are important selling points of legumes [5], and have sustained the agricultural interest. Legumes attract bacteria that fixate atmospheric nitrogen, utilise nitrogen, and make it available in crop rotations. Multiple benefits go hand in hand with legumes' nitrogen fertilisation. The fixation of nitrogen diminishes the eutrophication of water courses by mineral fertilisers [7], reduces the emissions of the greenhouse gas nitrous oxide [8], and prevents carbon dioxide emissions related to fertiliser production. The energy costs of nitrogen fertilisers are substantial. N-fertilisation has been responsible for 52\% [9] of all energy used in the agricultural cropping process. N-production and use remains a key issue of agriculture [10]. 
Besides the lack of marketing campaigns, researchers have described a lack of innovation [6]. Today, as well as in the previous decades, most legumes are sold in cans, followed by dried produce [6]. Packaging and distribution have hardly been changed [5]. However, some new legume products have entered retail, and are in the process of creating niche markets. Due to good processing qualities with respect to solubility, water binding capacity, fat binding, emulsifying, and foaming, legumes can be implemented in many convenience products [11]. Companies have utilised these processing characteristics in order to create innovative products. Lupine ice-cream or lupine yoghurt were developed to substitute milk for vegans and lactose intolerant consumers, while retaining texture and protein content. Another product is pea or chickpea pasta, which substitutes wheat to target consumers who are wary towards gluten. Pea milk or lupine spreads are also marketed. However, these products are specifically designed to substitute a certain ingredient for nutritional reasons. We are not aware of any efforts to develop the consumers' image of legumes in general, or to utilise their ecological advantages in product communication. Especially, new products may be able to create new and positive perceptions with consumers. Such product communication may reduce the environmental impact of food consumption by influencing purchase behaviour [12] in favour of legumes.

Product claims, i.e., health and environmental claims, are an opportunity to communicate product advantages that shall lead to a higher WTP and additional demand for legume products. The worth is not limited to individual products, but claims, as a common form of product communication, can highlight positive features of the whole product category. For example, cereal processors have undertaken proactive campaigns and claim marketing with a considerable reach to increase consumers' awareness of the health benefits of cereals' fibre content [13]. An increased knowledge of legume benefits may trigger behavioural change and enhance consumption. Claims are known to enhance demand [14,15], as they make it easier for consumers to justify a decision [16]. Consumers tend to believe claims' content [14]. However, Mialon et al. [17] have analysed fibre claims on bread and muffins. They suggest the effect is small or non-existent, because most consumers are already aware of products' fibre content. Assuming a low level of knowledge on legume benefits, legumes are particularly suited to analyse a claim effect. The benefits may not be perceived by everyone and will vary by the information provided. The effect a claim has on consumers will also vary by individual characteristics or food attitudes, such as social norms [18], consumers' price sensitivity [19], the motivation to act on health information [13], and probably many more. Surprisingly, the major challenges of healthier and environmentally friendlier consumption are rarely examined simultaneously in relation to claims, which are so commonly used in product marketing. Many products do not qualify for both types of claims. So far, health practitioners and green marketers have tended to focus on either health or environmental marketing, depending on the regulatory framework given to them. Therefore, we know little about how a mix of health and environmental attributes performs relative to individual health and environmental claims.

To evaluate the direct worth of claims to different consumers and encourage the legume processor's use of it, we designed an experiment where we auctioned off new legume products under different claim conditions. The claims are applicable to and admitted for the legume products under research in the following, but are certainly not limited to them. We assess the value of the claims individually and combined in order to analyse the advantage of incorporating both health and environmental claims. Food attitudes that go hand in hand with a higher valuation of the products are also considered. To produce reliable evidence, we propose two research necessities. Prior studies have emphasised the need to avoid purely attitudinal studies and build on non-hypothetical behavioural measures. "Consumers talk health or talk green, but don't walk it" [20]. An auction shall separate what they say from what they pay [21]. In addition, external validity is often an issue in samples recruited for on-site laboratory experiments [22]. Low external validity may cause an overestimation of the effect magnitudes. In an effort to resemble the marketplace, we execute an online auction with a quoted sample of household shoppers, representative in age, gender, and income. Before presenting 
the results, we discuss health and environmental claims and the specific features of our online auction; a singularity of this study.

\section{Operationalised Health and Environmental Claims}

Green peas are the majorly grown legumes in the EU [2]. We evaluate green pea pasta (PP), as pasta is a popular product that most consumers know how to utilise. It is a pure product derived from $100 \%$ pea flour to avoid distortion by consumers' perception of additives and so on. To anchor our findings, we also evaluate chickpea pasta (CP). Particularly, $\mathrm{CP}$ has been proven to increase the glycaemic index less than wheat pasta [23]. The substitute, classic wheat pasta (WP), is also auctioned. All the pastas are presented in see-through foil with a package size of $250 \mathrm{~g}$ (see product pictures, Appendix A Figure A1). All the pastas are available in German and Dutch retail outlets.

To initially test the value of legume benefits in marketing, we select two health and two environmental claims, applicable to legume pasta. The claims are tested individually and in a combination of both health and environmental claims. The claims refer to protein content $(\mathrm{H} 1)$, fibre content (H2), mineral fertiliser (E1), and carbon emissions (E2). All the claims are structured similarly and are presented on the product visuals used in the auction (Appendix A Figure A1). Several studies have found claims to influence willingness to pay (WTP) with consumers [24-26]. Effects can exist regardless of whether the advantage is of immediate concern to the consumer, as found for health claims on cholesterol [24]. A believable claim should increase WTP, if other product features are not compromised [26]. However, the effect is expected to be rather heterogeneous. For example, many consumers react positively to health information, but not all appear to place a monetary premium on health attributes [26].

The legislative framework of health claims requires extensive and generalisable research to avoid incorrect claim assignments, so most products may only carry a nutritional health claim. Indisputably, legumes provide rich protein and rich fibre content. The fibre content can also be linked to health benefits $[11,27]$. In consideration of the current legal framework of legumes, we select the fibre and protein content claims. The content is particularly different between legume and conventional pasta. The EU regulates the percentage required to use claims, respectively. The following claim can be made on the legume pasta used: "high in protein". The protein energy share in providing kcal needs to be larger than $20 \%(\mathrm{PP}=31 \%, \mathrm{CP}=20 \%, \mathrm{WP}=13 \%)$. The "high in fibre" claim requires a content greater than $6 \mathrm{~g}$ per $100 \mathrm{~g}(\mathrm{PP}=16.6 \mathrm{~g}, \mathrm{CP}=14 \mathrm{~g}$, WP $=3 \mathrm{~g})$ [28]. Standard wheat pasta does not fulfil the requirements for these claims. The fibre content has been of interest to health practitioners and marketers $[17,25,26]$. Dietary fibre claims have been analysed with respect to bakery products. While the claim "high in fibre" (H2) has been found consistently to enhance product liking, flavour, and healthiness perceptions, the effect has not always been significant [17]. Products that are commonly perceived to be high in fibre may not be affected by fibre claims [17]. An experimental auction on French baguettes with a "source of fibre" claim revealed a WTP increase of around 12\% [25]. In contrast, protein claims have not been studied to the best of our knowledge, despite protein content being a common claim in the marketplace, for example dairy products by Arla Foods. Such claims are attribute-based and describe a product attribute and not the utility derived from it. Permitted utility claims are limited; see the EU Commission for authorised claims [28]. Protein sources may mention a positive effect on bones and muscles. Legume claims describing the utility derived from fibre are currently neither admitted nor filed. The success of the claims in marketing depends on consumers' expectations, with respect to fibre and protein.

While prior findings have favoured shorter claims [29], environmental labelling research has found just "environmental friendly" to be too vague to be convincing [12]. A concrete attribute claim may have just the right information structure for consumers to be affected. Some consumers indicate a general preference for products labelled with their carbon footprint $[30,31]$ and might be persuaded to change their valuation of legumes based on carbon information. We assume lower carbon emissions for the legume pasta. From life cycle assessment research, it is known that legumes 
are one of the most climate-friendly sources of protein [32]. Compared with common plant-based calories, like wheat, legumes are expected to demand a lower carbon footprint. For example, peas have been shown to demand approximately half the non-renewable energy input per hectare, while the output gap is smaller, leading to a significantly better energy output/input ratio than winter and summer wheats [33]. The carbon advantage can be attributed to savings on nitrogen fertilisers. The EU has sued Germany with respect to the violation of agreements on nitrate application. Prior studies have confirmed that cropping details on chemical applications can affect WTP. Precise environmental information on pesticide use with apples enhances the WTP for offerings without it [34]. A contingent valuation with detailed information on farming systems and sustainable pesticide use substantially increases consumers' valuation of fruit and vegetable baskets, although it discourages the major share of low-income consumers from purchasing [35]. Legumes' ability to fixate nitrogen and evade corresponding agricultural needs holds an advantage that consumers may value, if they perceive the issues surrounding mineral fertilisers to be alarming.

\section{Experimental Design}

The experiment was split into four blocks. Before the first block consumers are asked to declare readiness to participate in a binding auction and their involvement in household's food shopping. The first block evaluates socio-demographic characteristics in order to guide a good representation of German consumers, with respect to gender, age, and income. The second block evaluates attitudes towards food. The attitudes control for some of the heterogeneity between consumers. Next, consumers are directed to the auction platform, where they have to agree to the terms and condition of the auction before they can place a bid. The auction process is combined with control questions to ensure auction comprehension, and the reading of claims on the product visuals. The experiment closes with product specific questions. We explain the food attitudes and, especially, the auction mechanism in more detail in the following.

\subsection{Food Attitudes}

With a group of marketing researchers we selected attitudes that may be linked to the WTP for legume products. We briefly state the idea behind the concepts. The willingness to act on health information differs between individuals, and will affect the demand for healthier products $[17,29,36]$. Regarding purchase motives, the straightforward role of sensory characteristics, like appearance, has been established [17]. A meta study by Moser et al. [37] found visual appeal to be a major determinant of fruit and vegetable purchases in Europe. The next concepts relate to the price sensitivity that may explain restrained biddings. Legume-specific social barriers have been derived in qualitative interviews $[5,38]$. Social desirability and flatulence appear to be salient concerns stated by consumers [38]. Altogether, the evaluated concepts are (the source of the items is cited following the concept title): concern for health in eating habits [39], visual (product) attractiveness [40], consumers' price sensitivity [19], and the perception of social barriers with respect to legume consumption [5,38]. A confirmatory factor analysis condenses the items into factors (Table 1). Five food choice factors are derived. The perception of flatulence differs from the other social barriers considered. Due to the frequently expressed objections caused by flatulence $[6,38]$, it is evaluated as an individual barrier. Other items are dropped if the factor loadings are smaller than 0.6. The visual attractiveness of pea and chickpea pastas appears to be similar. A positive attractiveness score of one product goes hand in hand with the other. A combined attractiveness factor is used for both products. 
Table 1. Confirmatory factor analyses of food attitudes.

\begin{tabular}{|c|c|c|c|c|c|}
\hline Variables & Scaling & Wording & $\varnothing$ & SD & FL \\
\hline \multicolumn{6}{|c|}{ Factor 1: price sensitivity $\alpha=0.68, \mathrm{KMO}=0.66, \mathrm{EV}=0.61, \mathrm{BT}=0.000$} \\
\hline price 1 & \multirow{3}{*}{ LS } & I always check prices, even on small items & 2.22 & 1.20 & 0.63 \\
\hline price 2 & & I notice when products I buy regularly change in price & 1.85 & 0.99 & 0.67 \\
\hline price 3 & & I watch for ads and plan to take advantage & 2.19 & 1.31 & 0.68 \\
\hline \multicolumn{6}{|c|}{ Factor 2: health concern (in diets) $\dot{\alpha}=0.8, \mathrm{KMO}=0.81, \mathrm{EV}=0.56, \mathrm{BT}=0.000$} \\
\hline health 1 & & keeps me healthy & 1.74 & 0.88 & 0.80 \\
\hline health 2 & It is important to me & is high in fibre and roughage & 2.48 & 1.10 & 0.78 \\
\hline health 3 & that the food I eat on & is nutritious & 1.70 & 0.86 & 0.61 \\
\hline health 4 & a typical day: (LS) & is high in protein & 2.82 & 1.12 & 0.73 \\
\hline health 5 & & is good for my skin/teeth/hair/nails, etc. & 2.37 & 1.14 & 0.80 \\
\hline \multicolumn{6}{|c|}{ Factor 3: visual attraction (of products) $\dot{\alpha}=0.76, \mathrm{KMO}=0.68, \mathrm{EV}=0.59, \mathrm{BT}=0.000$} \\
\hline visual 1 & \multirow{4}{*}{ LS } & This PP is visually appealing & 2.50 & 1.36 & 0.74 \\
\hline visual 2 & & This PP is colourful & 2.00 & 1.20 & 0.80 \\
\hline visual 3 & & This $C P$ is visually appealing & 2.15 & 1.11 & 0.75 \\
\hline visual 4 & & This $\mathrm{CP}$ is colourful & 1.96 & 1.03 & 0.78 \\
\hline \multicolumn{6}{|c|}{ Factor 4: social barriers $\dot{\alpha}=0.72, \mathrm{KMO}=0.66, \mathrm{EV}=0.65, \mathrm{BT}=0.000$} \\
\hline social 2 & \multirow{3}{*}{$\begin{array}{l}\text { Peas and beans are: } \\
\text { (LS) }\end{array}$} & not classy & 4.20 & 1.05 & 0.77 \\
\hline social 3 & & poor people's food & 4.47 & 0.83 & 0.85 \\
\hline social 4 & & consumed only by organic consumers & 4.41 & 0.89 & 0.79 \\
\hline \multicolumn{6}{|c|}{ Factors 5 flatulence perception } \\
\hline social 1 & LS & Peas and beans are promoters of flatulence & 2.85 & 1.18 & 1.00 \\
\hline
\end{tabular}

\subsection{Online Auction Design}

A variety of methods can be applied to estimate consumers' willingness to pay for products, each offering advantages and disadvantages. WTP measures based on discrete choice methods are less suitable, because the claims under research are not interchangeable attributes. The high protein content or fertiliser advantages exist with all legumes, and cannot be controlled by the production mechanisms. Food product claims are mostly evaluated with experimental auctions, in which the consumers bid for a product and/or a claim-treated product, e.g., [25,26,39,41].

\subsubsection{Auction Mechanism}

Focusing on experimental auctions, we avoid hypothetical bias and involve actual product purchase. Vickrey auctions are common to analyse the effect of information on WTP for food products $[25,26,39,41]$. Vickrey auctions reduce our logistical costs relative to Becker-DeGrootMarschak (BDM) auctions. A BDM auction creates an unknown number of purchases. A large online sample in a BDM auction may impose high logistical costs, while the Vickrey auction produces a projectable amount of purchases. We apply a standard second-price Vickrey auction. The auction winner is obliged to purchase the pasta for the price of the second-highest bid.

Financial endowments have been found to influence bids [42]. Consumers can be more willing to spend money that they received freely [43]. In this study no financial endowment is paid. Consumers should stand by their bid with their own resources and not be influenced by the endowment. However, it should be noted that survey participation is always rewarded with $€ 2$ by the market research agency, independent of whether an auction is involved. The winning bids are not revealed until after the auction ended, which would also influence bidding behaviour [43]. We advised the participants to reveal their true WTP as the best strategy throughout the experiment. 


\subsubsection{Online Setting}

An online setting is not common for experimental auctions, rather, laboratory experiments are used. The advantages of online settings are the large observation number with low costs, and the reduced risk of participants being interested in pleasing the experimenter. The online sample is an attempt to represent German consumers accurately. The disadvantages may include a lack of personalised instructions on the auction mechanism, product depreciation due to delayed receiving, or the issue of predominant opt-out choices, as participants may not be willing to bid in an online setting. Several steps are taken to minimise the disadvantages. We choose an auction which is simple to explain [26]. After the instructions, we perform a test auction (with a pen), followed by a question on the understanding of the auction mechanism. Instead of one auction for the whole sample, daily ones ( 5 days) are set up to increase the involvement and reduce the waiting time regarding product distribution. In total, $5 \times 3$ products $(\mathrm{PP}, \mathrm{CP}$, and $\mathrm{WP})$ are auctioned. Consumers are unaware of the number of participants in their session. The number varied between 105 and 335 observations per day. The mean bids between days are predominantly not significantly different. Additional quality checks control for irregular responding behaviour, namely streamlining (the time spent on a set of questions/products) and the overall time spent on the experiment. About $10 \%$ of the completed questionnaires had to be excluded due to quality concerns.

\subsubsection{Auction Flow}

Typically a laboratory experiment moves from a situation of no information, just the product, to full information, with all treatments executed. In contrast to such a within design, the claim-treatments can be assigned between consumers, so that each consumer is presented with the product in just one specification. The between-designed experiment requires larger sample sizes in order to compare well-balanced treatment groups, but consumers are not consciously judging the value of an added claim. Consumers evaluate the product given to them once, which may resemble a retail setting where a product is presented either with or without a claim. The larger sample size in this study enables an application of a between designed experiment.

Consumers are split into five treatment conditions and one control group; each treatment group is presented with a different claim on the product visual (Appendix A Figure A1). Participants were not given a channel to interact. The assignment of treatments is unconditionally randomised. The group sizes are not levelled. Exceptionally, individuals have double the probability of being assigned to the control group.

Three bidding rounds are performed. Each round, the bid for one of the products is collected (PP, $\mathrm{CP}, \mathrm{WP}$ ). The products are auctioned in a randomised order, as the first auction may influence the bid for the second one, so order effects could not bias the results. Each auction round has a new randomised process of assigning the treatments. The rounds are supplemented by control questions regarding the understanding of the auction process and the reading of the claims. Each round is binding to the auction winner. Participants agreed to the terms and conditions of the auctions and are made aware that the auction winner will be invoiced afterwards. In agreement with the market research agency, no further steps have been taken to collect the bids from auction winners. The individual success in the auction is announced to all the participants after the auction ended. The products are sent to the auction winners. The auction process was repeated over 5 days.

\section{Results}

\subsection{Data}

In cooperation with a market research agency and an online auction service, we collected 1020 usable consumer responses. Addressing the response quota, 3504 consumers decided to start the survey advertised as a "food survey". Roughly two-thirds dropped out, because they did not wish to participate in a binding auction. Similar to laboratory experiments, many people are not willing 
to take part in such studies. In the final sample, about 35\% $(\mathrm{N}=356)$ and $37 \%(\mathrm{~N}=375)$ are still not willing to place a bid on green pea pasta (PP) or chickpea pasta (CP) (Appendix A Figure A2). The Legume products are expected to address a similar consumer group. The willingness to pay for PP $\left(\mathrm{WTP}_{\mathrm{PP}}\right)$ and for $\mathrm{CP}\left(\mathrm{WTP}_{\mathrm{CP}}\right)$ are correlated substantially $(\mathrm{r}=0.77)$. In the total sample, $\mathrm{PP}$ achieves the highest WTP with 69.7 cents, followed closely by CP with 65.4 cents (Table 2). The retail price in the niche market varies between 2 and $4 €$. Only a minority is willing to pay the current retail price (Appendix A Figure A2). Roughly $1 \%$ of the consumers are willing to pay more than $3 €$. The average WTP for wheat pasta (WP) is a fair estimation of the retail price with 45.1 cents (Table 2). Noteworthy, the standard deviation of WP (53.4 cents) is considerably smaller than for legume pasta, which implies a more homogeneous valuation of WP. The WTP gap between PP-WP (WTP PP-WP) and $\mathrm{CP}-\mathrm{WP}\left(\mathrm{WTP}_{\mathrm{CP}-\mathrm{WP}}\right)$ captures the price premium consumers bid for legume pasta and accounts for some of the market competition.

Table 2. Sample characteristics.

\begin{tabular}{|c|c|c|c|c|c|c|c|}
\hline \multirow[b]{2}{*}{ Bids } & \multirow[b]{2}{*}{ Scale $(N=1020)$} & \multicolumn{2}{|c|}{$\begin{array}{l}\text { Full Consumer } \\
\text { Sample }\end{array}$} & \multicolumn{2}{|c|}{$\begin{array}{c}\text { Potential } \\
\text { Customers[PP] }\end{array}$} & \multicolumn{2}{|c|}{$\begin{array}{c}\text { Potential } \\
\text { Customers }[\mathrm{CP}]\end{array}$} \\
\hline & & $\varnothing$ & SD & $\varnothing$ & SD & $\varnothing$ & SD \\
\hline $\mathrm{WTP}_{\mathrm{PP}}$ & \multirow{5}{*}{$€$-Cents } & 69.7 & 83.3 & 112.7 & 82.4 & & \\
\hline $\mathrm{WTP}_{\mathrm{CP}}$ & & 65.4 & 79.8 & & & 109.4 & 79.0 \\
\hline $\mathrm{WTP}_{\mathrm{WP}}$ & & 45.1 & 53.4 & 56.3 & 62.9 & 56.3 & 54.2 \\
\hline $\mathrm{WTP}_{\mathrm{PP}-\mathrm{WP}}$ & & 24.6 & 65.8 & 56.4 & 62.9 & & \\
\hline \multirow[t]{2}{*}{$\mathrm{WTP}_{\mathrm{CP}-\mathrm{WP}}$} & & 20.3 & 64.1 & & & 53.1 & 61.1 \\
\hline & Socio-demographics & & & & & & \\
\hline gender & Gender: $0=$ male, $1=$ female & 0.50 & 0.50 & 0.52 & 0.50 & 0.52 & 0.50 \\
\hline age & in years & 46.78 & 14.71 & 46.17 & 14.10 & 46.13 & 14.64 \\
\hline income & $1 \leq 900 €, 9 \geq 6000 €$ per $\mathrm{HH}$ & 4.80 & 2.15 & 4.82 & 2.12 & 4.76 & 2.14 \\
\hline education & $\begin{array}{l}1=\text { no educational degree, } 4=\text { general qualification } \\
\text { for university entrance level }\end{array}$ & 3.32 & 0.75 & 3.40 & 0.71 & 3.39 & 0.74 \\
\hline $\mathrm{N}$ & & \multicolumn{2}{|c|}{1020} & \multicolumn{2}{|c|}{601} & \multicolumn{2}{|c|}{577} \\
\hline
\end{tabular}

Turning to the different treatments groups, the randomisation was successful in the sense that socio-demographic characteristics and food attitudes are balanced over the treatment groups, so that we cannot reject the assumption of equal distributions over the treatment groups (Table A1). Unobserved characteristics are not systematically different between the randomised treatment groups and are expected to be balanced. The descriptive data shows that the control group has a strong tendency to receive for the lowest mean bids, while the mix of all claims has a strong tendency to achieve the highest mean bids (Table 3). Looking into relevant consumers for legume products, the sample needs to be restricted to potential customers. Potential customers are filtered by dropping Zero-bid (opt-out) consumers and consumers who bid less for legume pasta than WP. For these consumers, the average gap between legume and wheat pasta varies between 41 cents and 70 cents (Table 3). 
Table 3. Auction bids by treatment.

\begin{tabular}{|c|c|c|c|c|c|c|c|}
\hline \multirow[t]{2}{*}{ Bids } & & \multicolumn{6}{|c|}{ Full Sample } \\
\hline & & $\mathrm{C}$ & H1 & H2 & E1 & E2 & Mix \\
\hline $\mathrm{WTP}_{\mathrm{PP}}$ & \multirow{8}{*}{$€$-cents } & 63.9 & 68.1 & 72.7 & 75.6 & 71.0 & 74.0 \\
\hline$(\mathrm{SD} \mid \mathrm{N})$ & & $77.4 \mid 313$ & $77.2 \mid 127$ & $81.9 \mid 141$ & $93.1 \mid 150$ & $84.9 \mid 155$ & $91.0 \mid 134$ \\
\hline $\mathrm{WTP}_{\mathrm{CP}}$ & & 61.9 & 65.0 & 66.3 & 61.9 & 69.6 & 71.6 \\
\hline$(\mathrm{SD} \mid \mathrm{N})$ & & $75.3 \mid 287$ & $74.7 \mid 146$ & $80.9 \mid 131$ & $73.3 \mid 164$ & $91.4 \mid 139$ & $87.8 \mid 153$ \\
\hline WTP PP-WP & & 16.8 & 23.3 & 27.5 & 27.2 & 27.7 & 35.0 \\
\hline$(\mathrm{SD} \mid \mathrm{N})$ & & $59.8 \mid 313$ & $57.0 \mid 127$ & $65.6 \mid 141$ & $66.1 \mid 150$ & $65.9 \mid 155$ & $83.4 \mid 134$ \\
\hline \multirow{3}{*}{$\begin{array}{c}\mathrm{WTP}_{\mathrm{CP}-\mathrm{WP}} \\
(\mathrm{SD} \mid \mathrm{N})\end{array}$} & & 18.7 & 18.8 & 18.7 & 18.6 & 19.6 & 28.7 \\
\hline & & $59.0 \mid 287$ & $60.0 \mid 146$ & $68.6 \mid 131$ & $53.1 \mid 164$ & $79.6 \mid 139$ & $68.3 \mid 153$ \\
\hline & & \multicolumn{6}{|c|}{ Potential Customer Sample, if $\mathrm{WTP}_{\mathrm{PP}, \mathrm{CP}} \geq \mathrm{WTP}_{\mathrm{WP}}>0$} \\
\hline $\mathrm{WTP}_{\mathrm{PP}}$ & \multirow{8}{*}{$€$-cents } & 106.2 & 107.6 & 113.1 & 121.5 & 117.0 & 116.4 \\
\hline$(\mathrm{SD} \mid \mathrm{N})$ & & $76.6 \mid 175$ & $73.9 \mid 77$ & $80.0 \mid 86$ & $93.5 \mid 91$ & $82.6 \mid 91$ & $91.5 \mid 81$ \\
\hline $\mathrm{WTP}_{\mathrm{CP}}$ & & 102.2 & 111.8 & 109.8 & 97.2 & 125.5 & 121.7 \\
\hline$(\mathrm{SD} \mid \mathrm{N})$ & & $75.2 \mid 166$ & $67.9 \mid 77$ & $80.7 \mid 76$ & $71.6 \mid 101$ & $94.1 \mid 72$ & $86.5 \mid 85$ \\
\hline $\mathrm{WTP}_{\mathrm{PP}-\mathrm{WP}}$ & & 48.1 & 50.8 & 58.3 & 59.9 & 59.8 & 69.8 \\
\hline$(\mathrm{SD} \mid \mathrm{N})$ & & $56.3 \mid 175$ & $52.2 \mid 77$ & $61.7 \mid 86$ & $55.9 \mid 91$ & $65.7 \mid 91$ & $86.3 \mid 81$ \\
\hline \multirow{2}{*}{$\begin{array}{c}\mathrm{WTP}_{\mathrm{CP}-\mathrm{WP}} \\
(\mathrm{SD} \mid \mathrm{N})\end{array}$} & & 47.8 & 52.8 & 54.9 & 41.4 & 67.0 & 64.0 \\
\hline & & $55.0 \mid 166$ & $55.9 \mid 77$ & $60.9 \mid 76$ & $52.1 \mid 101$ & $76.9 \mid 72$ & $69.4 \mid 85$ \\
\hline \multicolumn{8}{|c|}{ 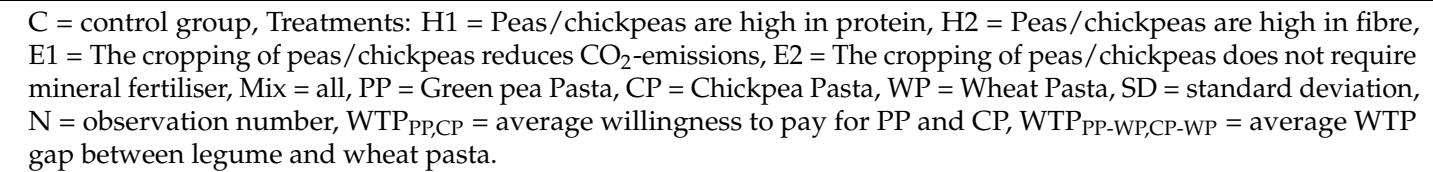 } \\
\hline
\end{tabular}

\subsection{The Causal Effect of Environmental and Health Claims}

Describing the value of environmental and health claims to new legume products, we model the causal effect (in $€$-cents) a claim has on the WTP. Considering how products compete in the market place with substitutes, we model the price difference consumers pay for the legume product relative to the common substitute. To identify the claims' effect, we restrict our sample to potential customers with two basic assumptions. Firstly, potential customers must be willing to pay a price for legume pasta. Consumers choosing to Opt-Out, i.e., a zero bid, cannot become customers. Secondly, potential customers are limited to consumers who are willing to bid equal or more for the legume than for the wheat product (if $\mathrm{WTP}_{\mathrm{PP}, \mathrm{CP}} \geq \mathrm{WTP}_{\mathrm{WP}}>0$ ). Estimating the effects of an econometric model can control for observed consumer characteristics in contrast to binary approaches. In accordance with prior experimental auctions [26,44], we apply a generalised Tobit regression model. Similar to these studies, the lower bound of the Tobit is set to zero and the upper bound to 5 , which represents the maximum retail price observed. The cut-off at zero is only applicable for the price premium model, if the sample can be limited to consumers whose price premium is positive or zero. The model specification includes socio-demographics and food attitudes in the Tobit. We will interpret the associations of such consumer characteristics with the WTP. The bids for wheat pasta have also been partially treated with health claims. In both models, we control for the treatment received on wheat pasta. The variability of bids may be unequal across the range of values of a second variable that predicts it, which can be of concern in experimental auctions, e.g., [26]. We use (heteroscedasticity) robust standard errors.

Looking into the causal effect of environmental and health claims, we note that claims can be expected to increase the WTP for legume pasta. Consumers who did not receive the claim tend to be unaware or do not judge the value of legume products in consideration of legume benefits. The health claims regarding fibre (H2) and regarding protein (H1) achieve consistently over two products a higher WTP than the control group. The effect varies between 3 and 12 cents (Table 4), while the 
fibre claim appears superior to the protein claim, but both claims fail to achieve an effect at standard significance levels. The environmental claims on $\mathrm{CO}_{2}$-emissions (E1) and fertiliser (E2) achieve effect magnitudes at least comparable to the fibre claim. Again, a significant effect cannot be confirmed in both models. Most convincingly, the mix of all claims achieves a consistent and significant effect on WTP. The average effect size varies between 19 and 22 cents (Table 4). The effect may not double the effect of any individual claims, but reveals that a mix of health and environmental claims is most successful with potential customers.

Table 4. Claims' and food attitudes' marginal effect on the potential customers.

\begin{tabular}{|c|c|c|c|c|c|}
\hline \multirow{2}{*}{\multicolumn{2}{|c|}{ Tobit }} & \multirow{2}{*}{\multicolumn{2}{|c|}{$\begin{array}{c}\text { Green pea Pasta (PP) } \\
\text { WTP }_{\text {PP-WP }}\end{array}$}} & \multirow{2}{*}{\multicolumn{2}{|c|}{$\frac{\text { Chickpea Pasta (CP) }}{\text { WTP }_{\text {CP-WP }}}$}} \\
\hline & & & & & \\
\hline Variables & Scaling Direction & ME & SE & ME & SE \\
\hline $\mathrm{H} 1$ & & 9.4 & 8.5 & 4.9 & 9.3 \\
\hline $\mathrm{H} 2$ & & 13.9 & 9.1 & 10.3 & 9.7 \\
\hline E1 & Treatment vs. Control Group & $14.9 *$ & 8.6 & -6.6 & 8.1 \\
\hline E2 & & 12.4 & 9.5 & 16.5 & 11.0 \\
\hline Mix & & 21.4 * & 12.5 & $21.6^{* *}$ & 9.4 \\
\hline Price [std] & $\rightarrow$ less price sensitive & $6.0 *$ & 3.3 & $6.0 *$ & 3.6 \\
\hline Health [std] & $\rightarrow$ less concern for health & -4.6 & 3.5 & $-8.7^{* *}$ & 3.4 \\
\hline Visual [std] & $\rightarrow$ less attracted to visual & $-11.2^{* * *}$ & 3.4 & -4.3 & 3.3 \\
\hline Social [std] & $\rightarrow$ disagrees with social barrier & 2.2 & 3.4 & $8.4^{* * *}$ & 3.1 \\
\hline Flatulence [std] & $\rightarrow$ disagrees with flatulence issue & $5.5^{*}$ & 3.1 & $9.6^{* * *}$ & 3.3 \\
\hline Gender $[0,1]$ & $\rightarrow$ women & $11.3^{*}$ & 6.1 & $16.9^{* * *}$ & 6.3 \\
\hline Age [years] & $\rightarrow$ older & -0.1 & 0.3 & $-0.5^{* *}$ & 0.2 \\
\hline Income [std] & $\rightarrow$ higher income & $5.7 *$ & 3.2 & 0.6 & 1.4 \\
\hline Education [std] & $\rightarrow$ higher education & -1.8 & 3.3 & 2.8 & 4.2 \\
\hline $\mathrm{N}$ & & & & & \\
\hline Prob $>\mathrm{chi}^{2}$ & & & & & \\
\hline
\end{tabular}

$\mathrm{WTP}_{\mathrm{PP}, \mathrm{CP}-\mathrm{WP}}=\mathrm{WTP}$ gap between legume and wheat pasta, $\mathrm{ME}=$ marginal effects (outcome in $€$-cents), $\mathrm{SE}=$ heteroscedasticity robust standard error of regression coefficient, Significant levels $*=10 \%,{ }^{* *}=5 \%,{ }^{* * *}=1 \%$, $\mathrm{H} 1=$ Peas / chickpeas are high in protein, $\mathrm{H} 2=$ Peas / chickpeas are high in fibre, E1 = The cropping of peas/chickpeas reduces $\mathrm{CO}_{2}$-emissions, $\mathrm{E} 2=$ The cropping of peas/chickpeas does not require mineral fertiliser, Mix = H1 + H2 + $\mathrm{E} 1+\mathrm{E} 2$.

\subsection{Food Attitudes Relationship with WTP}

Most control variables are standardised so that their coefficients can be compared. The magnitude can be interpreted as a change in WTP associated with a change by one standard deviation of the independent variable. Unsurprisingly, among potential customers the WTP is still heterogeneous. Several food attitudes are significantly linked with a higher WTP, however, the link may vary depending on whether chickpeas or green peas are evaluated. While the direction of the link is predominantly the same for both products, the strength of the link can vary. A higher concern for health in eating habits or social barriers to legumes is a significant factor for the purchase of $\mathrm{CP}$ and not for PP (Table 4). Similarly, being visually attracted to the product appears to be more important with the green PP than the yellow / orange CP (Table 4). To consider oneself price sensitive is equally linked to PP and CP. Flatulence reservations can matter with both products. Further, women can be linked to higher bids. Younger consumers bid more for the chickpea product than older ones, and higher income consumers can be associated with higher bids for the green pea product.

\section{Discussion}

Researchers (and marketers) need to think about the aspects of the products that are most appealing to consumers [12]. Legumes offer various health and environmental benefits that we have discussed. Claims regarding such benefits may optimise behaviour due to a demand increase for 
healthier and environmentally friendlier products. The short information provided in a claim is a low-cost opportunity to encourage purchase and to spread knowledge on legumes. Estimating the potential of claims on new legume products, we show the causal effect of four claims on the WTP for green pea (PP) and chickpea pasta (CP). The health claims concern the high protein (H1) and high fibre $(\mathrm{H} 2)$ content of the products. The environmental claims, which are not applied in practice for any legume product, deal with $\mathrm{CO}_{2}$-emissions and fertilisers. The tested claims for legumes are founded on, to our knowledge, unchallenged evidence. The claims are formulated on a legume type basis and can be used interchangeably for many legume products.

We discuss the findings on WTP for legumes relative to wheat pasta. The claims increase the WTP for legume pasta. The effect size is heterogeneous with high standard deviation, so that individual claims predominantly fail to achieve standard significance levels. The results do not imply that the admitted health claims are superior to environmental claims, although acting on environmental claims is motivated by altruistic instead of personal motives. Building on the individual claims, the results reveal that a combination of the health and environmental benefits is most successful and increases the average WTP of potential customers by about 20 cents. The combination of personal health and interpersonal environmental benefits helps consumers to justify a higher price and possibly the switching to a new product.

Environmental benefits are impersonal and delayed, so it is often hypothesised that consumers only pay a price premium if the environmental benefits are connected to private ones [12,20]. Indeed, labelling studies on organic products, which claim environmentally friendlier production, have observed a mix of effective purchase drivers. They have reported quality and health criteria as decisive drivers rather than environmental concerns [45]. The recent study by Becker et al. [45] contradicted the health role in organic purchases. It identified environmental awareness as a primary driver of organic purchases. While a mix of environmental and health messages remains the most recommendable option, the findings of Becker et al. [45] imply an increasing demand for environmental messages in marketing.

Claims on $\mathrm{CO}_{2}$ emissions are known as voluntary options for food processors. It is argued that carbon labelling enables consumers to make greener choices if the labels are mandatory to allow fair comparisons between products and product categories [30]. Prior studies approximate the amount of consumers interested in carbon labelling. The findings from Germany and Canada suggest that about one-fifth of consumers are ready to consider carbon information in their food choice [31]. A cluster of about one-third of UK consumers was found to show concern for sustainability and was interested in carbon labelling [30]. A message on pesticide use, framing environmental issues, respectively, has been found to be more effective than health messages on polyphenols with respect to apple purchases [34]. However, pesticide or fertiliser use may unwillingly send a health message to consumers. Independent of the rightfulness of health worries regarding fertilisers and residues, claiming the absence of fertiliser may create an additional health message that contributes to the effect on WTP.

The effect size of a claim relative to a no-claim situation is difficult to compare to earlier studies, because we apply an online design focusing on potential customers who represent about 56 to $59 \%$ of the full sample. The full sample mimics a cross-section of German consumers with quotas for gender, age, and income. The online auction allowed for the quoted recruitment process and the exclusion of the usual financial endowments. The online auction is a singularity of this study and needs to be validated in further applications. It depends on the perception of visuals. Evaluations by product visuals are found to produce equally credible WTP measures in comparison with including tactile or olfactorial factors in the mix [26]. A taste opportunity does not resemble a retail setting. However, a visual setting of unknown products resembles first purchases, but does not account for repeated purchases, which build on experiences rather than expectations. Sensory studies that allow consumers to taste the product tend to produce higher WTP estimates [39].

This online auction produced mean WTP measures for wheat pasta that closely resemble the retail prices and a mean WTP for the newly introduced legume pasta that falls short of the current retail 
prices, which only a minority is willing to pay. The observed retail prices cannot be justified by the higher costs for raw materials. Producers may use a price skimming strategy, whereas marketers set a relatively high initial price for a product or service at first, then lower the price over time. Noteworthy, a relatively high percentage ( 35 to $37 \%$ ) of the consumers were not willing to place a bid. The high percentage might be explained by features of the online setting or the absence of a direct financial endowment. Further mimicking a marketplace and increasing the external validity of samples, possibly by building on the online auction approach, will offer a reliable idea of consumers' decisions to buy healthier and greener products.

Looking into consumer characteristics, we find significant links, although the findings are not necessarily the same for green pea and chickpea pasta. Klemcke et al. [5] found that legumes are generally accepted to be healthy, and negative associations, such as flatulence, are of lesser importance to market legumes. We contradict the findings in a way, as potential customers, who perceive flatulence critical, have a significantly lower WTP for legume products. The healthfulness perception of legumes may also differ between green peas and chickpeas. We find potential customers' concern for health in eating habits to be associated with a higher WTP for chickpea but not for green pea pasta. The health concerns have been linked to choices for the supposedly healthier option over the classic alternative [39]. This implies that customers' perception of chickpeas is linked to a healthy food image, while green peas are not. The rising interest in health and diet links [39] suggests an increasing worth of such a food image. Social barriers point also to a different image between legume crops, because the chickpea product is affected by the factor on statements such as "consumed only by organic consumers", while green peas WTP cannot be linked to these perceptions. The visual attraction to a product has been found to significantly enhance consumption [40]. Again, the visual attraction mattered to the green pea pasta, while the yellow to orange colour of chickpea pasta, which is closer to the wheat version, could not be linked to WTP. Processors of new legume products may want to consider distinguishing the visual design of their product from the substitutes in order to increase the initial interest.

Analysing a wide range of socio-demographics, Togler and Garcia-Valiñas [46] find women and financially satisfied people to reveal stronger preferences for environmental protection. Less consistent tendencies indicate that younger and higher educated people reveal the same preferences. Women have also been linked to a higher WTP for products with health functions [39]. We find women to have a higher WTP for the legume products than men. The finding may or may not be based on stronger perceptions by women with respect to legumes being healthy and environmentally friendly. Lastly the WTP for chickpea pasta is higher with younger consumers if income is controlled for in the model. Therefore chickpea pasta may develop into a trendy product. The food attitudes and socio-demographic characteristics are linked to WTP, but are not necessarily a causal driver to WTP. We cannot exclude the possibility that a latent variable, not controlled for in the model, is the causal driver to WTP and correlated with a characteristic.

Reflecting on the current legislative framework for environmental claims, we want to note the trade-off between strict and lax regulations. Restrictive regulation is often regarded as favourable for consumer protection [14]. Stricter regulation of claims will surely build trust in claims and prevent unsubstantiated marketing. The drawback is the constraint of valid product benefits due to costly or time-intensive admission processes. For legumes, we observe that only soy beans, the most widely commercialised legume crop, has admitted health utility claims with the US Food \& Drug Administration (FDA). Soy processors may claim a reduced risk of heart diseases due to soy consumption [13]. The benefit is unlikely to be limited to soy. The introduction of health claim regulation provides the opportunity to research the trade-off between economic barriers of admission and trust in claims.

Lastly, the flatulence concern that restricts consumers' WTP for legumes could be tackled with research from public or private initiatives. A few breeding programmes have deviated from the classic success parameters in the field and incorporated taste and digestibility. Nevertheless, we are only aware of programmes acting in such a way for high-value crops such as wheat. These breeding efforts 
would be well received to encourage demand on legumes. The marketing of legumes is not restricted to the environmental benefits of $\mathrm{CO}_{2}$-emission and fertiliser savings. Other benefits and different marketing strategies to communicate benefits are plausible. Additional environmental benefits may include marketing the increased agricultural biodiversity with mixed legume cropping schemes [47] or legumes' contribution to a rooting system that improves soil properties.

Acknowledgments: Funded by the German Federal Ministry of Education and Research FKZ 031A35. We acknowledge support by the Open Access Publication Funds of the Göttingen University.

Author Contributions: Conceptualizing and refining research ideas: Dominic Lemken, Achim Spiller-Literature search: Dominic Lemken, Mandy Knigge—Creating research design: Dominic Lemken, Stephan Meyerding, Achim Spiller-Instrument construction and questionnaire design: Dominic Lemken, Mandy Knigge-Statistical analysis: Dominic Lemken - Collection and preparation of data: Dominic Lemken, Mandy Knigge-Interpretation of statistical analysis: Dominic Lemken, Drafting Manuscript: Dominic Lemken, Editing manuscript: Achim Spiller, Stephan Meyerding.

Conflicts of Interest: The authors declare no conflict of interest. 


\section{Appendix A}

Table A1. Socio-demographics and food attitudes by treatment.

\begin{tabular}{|c|c|c|c|c|c|c|c|c|c|c|c|c|c|c|c|c|}
\hline \multirow{2}{*}{ Treatment } & \multirow{2}{*}{ Total } & & $\mathrm{C}$ & E2 & E1 & H1 & H2 & Mix & & $\mathrm{C}$ & E2 & E1 & H1 & H2 & Mix & \\
\hline & & & \multicolumn{7}{|c|}{ Chickpea Pasta } & \multicolumn{7}{|c|}{ Green Pea Pasta } \\
\hline $\mathrm{N}$ & & & 288 & 141 & 165 & 146 & 131 & 153 & & 313 & 155 & 150 & 127 & 141 & 134 & \\
\hline Variables [Min-Max] & $\varnothing$ & SD & $\varnothing$ & $\Delta \varnothing$ & $\Delta \varnothing$ & $\Delta \varnothing$ & $\Delta \varnothing$ & $\underline{\Delta \varnothing}$ & Prob & $\varnothing$ & $\Delta \varnothing$ & $\Delta \varnothing$ & $\Delta \varnothing$ & $\Delta \varnothing$ & $\Delta \varnothing$ & Prob $>\mathrm{F}$ \\
\hline Gender $[0-1]$ & 0.50 & 0.50 & 0.50 & -0.06 & 0.05 & 0.03 & 0.03 & -0.06 & 0.22 & 0.48 & -0.06 & -0.01 & -0.01 & 0.02 & -0.07 & 0.54 \\
\hline age [19-86] & 46.78 & 14.71 & 46.98 & 0.24 & 1.03 & -0.96 & -0.10 & 1.00 & 0.85 & 47.13 & -0.26 & 2.16 & 1.69 & -0.59 & -0.47 & 0.45 \\
\hline Income [1-9] & 4.80 & 2.15 & 4.92 & -0.21 & 0.34 & 0.25 & 0.16 & 0.23 & 0.23 & 4.82 & -0.11 & -0.20 & 0.01 & 0.17 & 0.32 & 0.36 \\
\hline Educ $[1-4]$ & 3.32 & 0.75 & 3.34 & -0.09 & 0.04 & 0.11 & 0.07 & -0.03 & 0.29 & 3.27 & -0.03 & -0.15 & -0.10 & -0.08 & -0.03 & 0.42 \\
\hline Price_sens $[-1.2,3.2]$ & 0.00 & 1.00 & -0.03 & -0.06 & -0.04 & -0.07 & -0.06 & -0.01 & 0.97 & -0.03 & -0.12 & -0.01 & -0.09 & -0.01 & 0.02 & 0.80 \\
\hline Health_cc $[-1.6,3.7]$ & 0.00 & 1.00 & -0.05 & 0.01 & 0.00 & -0.28 & -0.04 & -0.05 & 0.08 & -0.06 & -0.13 & -0.09 & -0.18 & -0.03 & -0.02 & 0.55 \\
\hline Visu_attract $[-1.3,3.4]$ & 0.00 & 1.00 & -0.05 & 0.04 & -0.19 & -0.04 & -0.05 & -0.10 & 0.38 & -0.02 & 0.01 & -0.08 & -0.07 & -0.02 & -0.02 & 0.95 \\
\hline Soc_barriers $[-4.6,0.9]$ & 0.00 & 1.00 & 0.00 & -0.07 & -0.02 & -0.00 & 0.07 & 0.05 & 0.88 & 0.03 & 0.09 & -0.01 & 0.28 & -0.06 & -0.06 & 0.051 \\
\hline Flatulence $[-1.6,1.8]$ & 0.00 & 1.00 & 0.00 & 0.00 & 0.01 & 0.03 & -0.00 & -0.02 & 0.99 & -0.02 & -0.05 & -0.10 & 0.01 & 0.07 & -0.04 & 0.78 \\
\hline
\end{tabular}

$\mathrm{H} 1=$ Peas/chickpeas are high in protein, $\mathrm{H} 2=$ Peas/chickpeas are high in fibre, $\mathrm{E} 1=$ The cropping of peas/chickpeas reduces $\mathrm{CO}_{2}$-emissions, $\mathrm{E} 2=\mathrm{The}$ cropping of peas /chickpeas does

variables, $\Delta \varnothing=$ control mean-treatment mean 


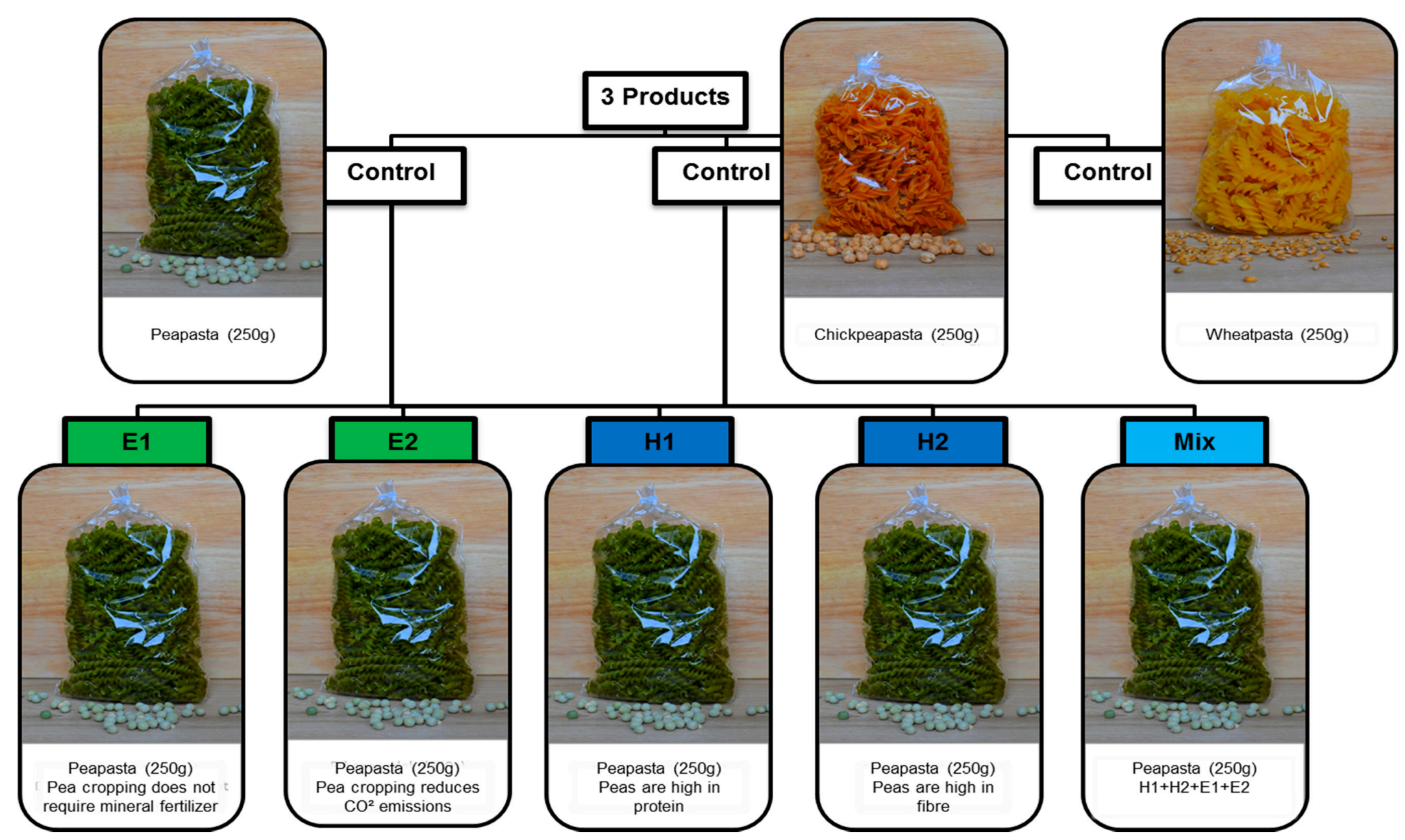

Figure A1. Design of product visuals and claims between treatments (Note: treatments exemplified for pea pasta, experimental design translated from German). 
Sustainability 2017, 9, 1340

15 of 18

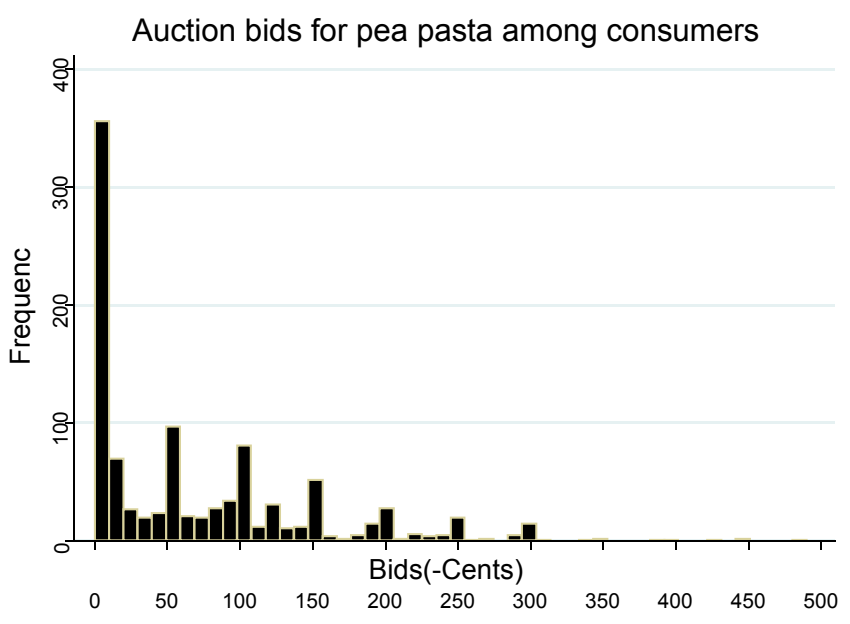

Price premium for pea over wheat pasta among potential customers

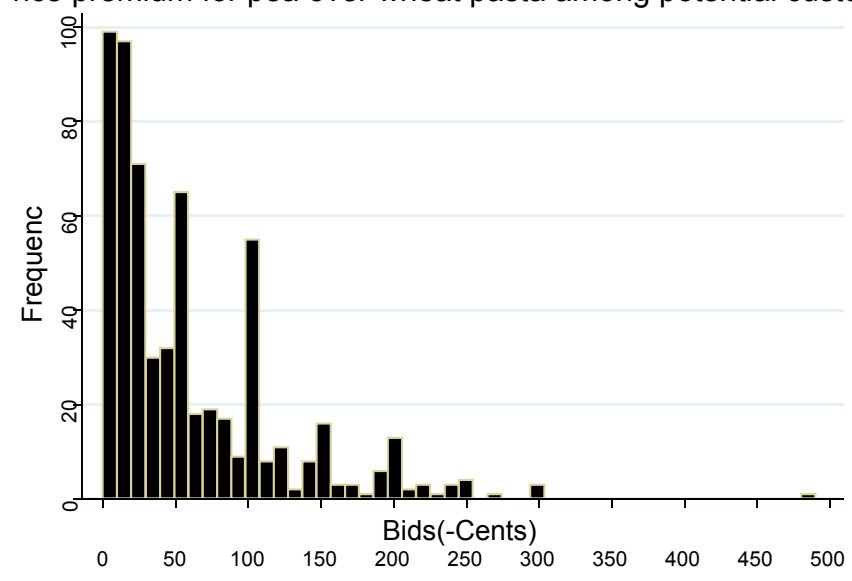

Auction bids for chickpea pasta among consumers

Price premium for chickpea over wheat pasta among potential customers
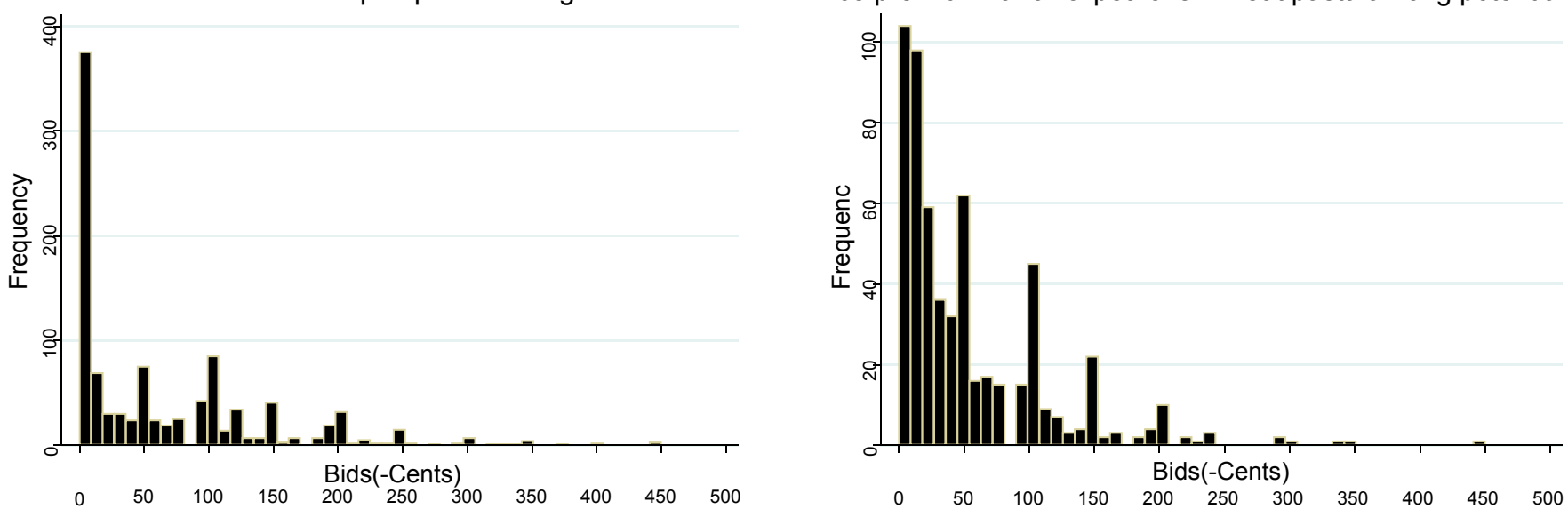

Figure A2. Distribution of bid estimates for legume pasta. 


\section{References}

1. Marlett, J.A.; McBurney, M.I.; Slavin, J.L. Position of the American dietetic association: Health implications of dietary fiber. J. Am. Diet. Assoc. 2002, 102, 993-1000. [CrossRef]

2. FAOSTAT. FAOSTAT Statistics Database; Food and Agriculture Organization of the United Nations: Rome, Italy, 2016.

3. Afshin, A.; Micha, R.; Khatibzadeh, S.; Mozaffarian, D. Consumption of nuts and legumes and risk of incident ischemic heart disease, stroke, and diabetes: A systematic review and meta-analysis. Am. J. Clin. Nutr. 2014, 100, 278-288. [CrossRef] [PubMed]

4. Bouchenak, M.; Lamri-Senhadji, M. Nutritional quality of legumes, and their role in cardiometabolic risk prevention: A review. J. Med. Food 2013, 16, 185-198. [CrossRef] [PubMed]

5. Klemcke, S.; Glende, S.; Rohn, S. The revitalisation of native grain legumes. Survey on buying habits and assessment of native grain legumes. Ernaehrungs Umschau Int. 2013, 4, 52-57. [CrossRef]

6. Schneider, A.V.C. Overview of the market and consumption of pulses in Europe. Br. J. Nutr. $2002,88$. [CrossRef] [PubMed]

7. Crews, T.; Peoples, M. Legume versus fertiliser sources of nitrogen: Ecological tradeoffs and human needs. Agric. Ecosyst. Environ. 2004, 102, 279-297. [CrossRef]

8. Senbayram, M.; Wenthe, C.; Lingner, A.; Isselstein, J.; Steinmann, H.; Kaya, C.; Köbke, S. Legume-based mixed intercropping systems may lower agricultural born $\mathrm{N}_{2} \mathrm{O}$ emissions. Energy Sustain. Soc. 2016, 6, 2. [CrossRef]

9. Rosen, C. World Resources 2000-2001: People and Ecosystems: The Fraying Web of Life; Elsevier: Amsterdam, The Netherlands, 2000.

10. Bodirsky, B.L.; Popp, A.; Lotze-Campen, H.; Dietrich, J.P.; Rolinski, S.; Weindl, I.; Schmitz, C.; Müller, C.; Bonsch, M.; Humpenöder, F.; et al. Reactive nitrogen requirements to feed the world in 2050 and potential to mitigate nitrogen pollution. Nat. Commun. 2014, 5, 3858. [CrossRef] [PubMed]

11. Vaz Patto, M.C.; Amarowicz, R.; Aryee, A.N.A.; Boye, J.I.; Chung, H.-J.; Martín-Cabrejas, M.A.; Domoney, C. Achievements and challenges in improving the nutritional quality of food legumes. Crit. Rev. Plant Sci. 2015, 34, 105-143. [CrossRef]

12. Taufique, K.M.R.; Siwar, C.; Talib, B.; Sarah, F.H.; Chamhuri, N. Synthesis of Constructs for Modeling Consumers' Understanding and Perception of Eco-Labels. Sustainability 2014, 6, 2176. [CrossRef]

13. Wansink, B.; Cheney, M. Leveraging FDA Health Claims. J. Consum. Aff. 2005, 39, 386-398. [CrossRef]

14. Aschemann-Witzel, J. Consumer acceptance of food with claims: Studies on consumer protection. Ernährungs Umschau 2010, 57, 238-242.

15. Lee, W.-C.J.; Shimizu, M.; Kniffin, K.M.; Wansink, B. You taste what you see: Do organic labels bias taste perceptions? Food Qual. Preference 2013, 29, 33-39. [CrossRef]

16. Belei, N.; Geyskens, K.; Goukens, C.; Ramanathan, S.; Lemmink, J. The Best of Both Worlds? Effects of Attribute-Induced Goal Conflict on Consumption of Healthful Indulgences. J. Mark. Res. 2012, 49, 900-909. [CrossRef]

17. Mialon, V.; Clark, M.; Leppard, P.; Cox, D. The effect of dietary fibre information on consumer responses to breads and "English" muffins: A cross-cultural study. Food Qual. Preference 2002, 13, 1-12. [CrossRef]

18. Kim, H.; Lee, E.J.; Hur, W.M. The Normative Social Influence on Eco-Friendly Consumer Behavior: The Moderating Effect of Environmental Marketing Claims. Cloth. Textiles Res. J. 2012, 30, 4-18. [CrossRef]

19. Grunert, K.G.; Brunsø, K.; Bredahl, L.; Bech, A.C. Food-Related Lifestyle: A Segmentation Approach to European Food Consumers. In Food, People and Society: A European Perspective of Consumers' Food Choices; Frewer, L.J., Risvik, E., Schifferstein, H., Eds.; Springer: Berlin, Germany, 2001; pp. 211-230.

20. Zandstra, E.H.; Miyapuram, K.P.; Tobler, P.N. Understanding consumer decisions using behavioral economics. Prog. Brain Res. 2013, 202, 197-211. [CrossRef] [PubMed]

21. Napolitano, F.; Braghieri, A.; Piasentier, E.; Favotto, S.; Naspetti, S.; Zanoli, R. Cheese liking and consumer willingness to pay as affected by information about organic production. J. Dairy Res. 2010, 77, 280-286. [CrossRef] [PubMed]

22. Wansink, B. Change Their Choice! Changing Behavior Using the CAN Approach and Activism Research. Psychol. Mark. 2015, 32, 486-500. [CrossRef] 
23. Goñi, I.; Valentin-Gamazo, C. Chickpea flour ingredient slows glycemic response to pasta in healthy volunteers. Food Chem. 2003, 81, 511-515. [CrossRef]

24. Marette, S.; Roosen, J.; Blanchemanche, S.; Feinblatt-Mélèze, E. Functional food, uncertainty and consumers' choices: A lab experiment with enriched yoghurts for lowering cholesterol. Food Policy 2010, 35, 419-428. [CrossRef]

25. Ginon, E.; Lohéac, Y.; Martin, C.; Combris, P.; Issanchou, S. Effect of fibre information on consumer willingness to pay for French baguettes. Food Qual. Preference 2009, 20, 343-352. [CrossRef]

26. Hellyer, N.E.; Fraser, I.; Haddock-Fraser, J. Food choice, health information and functional ingredients: An experimental auction employing bread. Food Policy 2012, 37, 232-245. [CrossRef]

27. Papanikolaou, Y.; Fulgoni, V.L., III. Bean Consumption Is Associated with Greater Nutrient Intake, Reduced Systolic Blood Pressure, Lower Body Weight, and a Smaller Waist Circumference in Adults: Results from the National Health and Nutrition Examination Survey 1999-2002. J. Am. Coll. Nutr. 2008, 27, 569-576. [CrossRef] [PubMed]

28. EU-Comission. EU Register of Nutrition and Health Claims Made on Foods. Available online: http: / / ec.europa.eu/nuhclaims / (accessed on 15 September 2016).

29. Pothoulaki, M.; Chryssochoidis, G. Health claims: Consumers' matters. J. Funct. Foods 2009, 1, $222-228$. [CrossRef]

30. Gadema, Z.; Oglethorpe, D. The use and usefulness of carbon labelling food: A policy perspective from a survey of UK supermarket shoppers. Food Policy 2011, 36, 815-822. [CrossRef]

31. Peschel, A.O.; Grebitus, C.; Steiner, B.; Veeman, M. How does consumer knowledge affect environmentally sustainable choices? Evidence from a cross-country latent class analysis of food labels. Appetite 2016, 106, 78-91. [CrossRef] [PubMed]

32. Nijdam, D.; Rood, T.; Westhoek, H. The price of protein: Review of land use and carbon footprints from life cycle assessments of animal food products and their substitutes. Food Policy 2012, 37, 760-770. [CrossRef]

33. Zentner, R.; Lafond, G.; Derksen, D.; Nagy, C.; Wall, D.; May, W. Effects of tillage method and crop rotation on non-renewable energy use efficiency for a thin Black Chernozem in the Canadian Prairies. Soil Tillage Res. 2004, 77, 125-136. [CrossRef]

34. Marette, S.; Messéan, A.; Millet, G. Consumers' willingness to pay for eco-friendly apples under different labels: Evidences from a lab experiment. Food Policy 2012, 37, 151-161. [CrossRef]

35. Costa, C.A.D.; Santos, J.L. Estimating the demand curve for sustainable use of pesticides from contingent-valuation data. Ecol. Econ. 2016, 127, 121-128. [CrossRef]

36. Contini, C.; Casini, L.; Stefan, V.; Romano, C.; Juhl, H.J.; Lähteenmäki, L.; Scozzafava, G.; Grunert, K.G. Some like it healthy: Can socio-demographic characteristics serve as predictors for a healthy food choice? Food Qual. Preference 2015, 46, 103-112. [CrossRef]

37. Moser, R.; Raffaelli, R.; Thilmany, D.D. Consumer Preferences for Fruit and Vegetables with Credence-Based Attributes: A Review. Int. Food Agribus. Manag. Rev. 2011, 14, 121-142.

38. Lea, E.; Worsley, A.; Crawford, D. Australian adult consumers' beliefs about plant foods: A qualitative study. Health Educ. Behav. 2005, 32, 795-808. [CrossRef] [PubMed]

39. Vecchio, R.; van Loo, E.J.; Annunziata, A. Consumers' willingness to pay for conventional, organic and functional yogurt: Evidence from experimental auctions. Int. J. Consum. Stud. 2016, 40, 368-378. [CrossRef]

40. Deng, X.; Srinivasan, R. When do transparent packages increase (or decrease) food consumption? J. Mark. 2013, 77, 104-117. [CrossRef]

41. Rozan, A.; Stenger, A.; Willinger, M. Willingness to pay for food safety: An experimental investigation of quality certification on bidding behaviour. Eur. Rev. Agric. Econ. 2004, 31, 409-425. [CrossRef]

42. Lusk, J.L.; Feldkamp, T.; Schroeder, T.C. Experimental Auction Procedure: Impact on Valuation of Quality Differentiated Goods. Am. J. Agric. Econ. 2004, 86, 389-405. [CrossRef]

43. Drichoutis, A.C.; Lazaridis, P.; Nayga, R.M., Jr. The role of reference prices in experimental auctions. Econ. Lett. 2008, 99, 446-448. [CrossRef]

44. Drichoutis, A.C.; Lazaridis, P.; Nayga, R.M. Would consumers value food-away-from-home products with nutritional labels? Agribusiness 2009, 25, 550-575. [CrossRef]

45. Becker, N.; Tavor, T.; Friedler, L.; Bar, P. Two stages decision process toward organic food: The case of organic tomatoes in Israel. Agroecol. Sustain. Food Syst. 2015, 39, 342-361. [CrossRef] 
46. Torgler, B.; García-Valiñas, M.A. The determinants of individuals' attitudes towards preventing environmental damage. Ecol. Econ. Coast. Disasters 2007, 63, 536-552. [CrossRef]

47. Lemken, D.; Spiller, A.; von Meyer-Höfer, M. The Case of Legume-Cereal Crop Mixtures in Modern Agriculture and the Transtheoretical Model of Gradual Adoption. Ecol. Econ. 2017, 137, 20-28. [CrossRef] 